\title{
Chronic lymphocytic leukemia manifested by steroid responsive polyneuropathy
}

\author{
Rajesh Rajput, Munish Batra, SB Siwach, Jagdish
}

\begin{abstract}
Abstrak
Kami laporkan seorang pasien dengan polineuropati akut karena demielinasi. Pada perjalanan penyakitnya ternyata menderita leukemia limfositik akut (stadium 0). Respons positif terhadap terapi steroid menimbulkan dugaan bahwa polineuropati dalam kasus ini merupakan proses autoimun. Leukemia limfositik akut dengan manifestasi polineuropati jarang dijumpai dalam literatu r.
\end{abstract} (Med J Indones 2003; 12: 27-8)

\begin{abstract}
We report a patient of acute demyelinating polyneuropathy who on investigations turned out to be suffering from chronic lymphocytic leukaemia (stage 0). Response to steroid therapy suggests an autoimmune process as a cause of polyneuropathy. Chronic lymphocytic leukaemia manifested by acute polyneuropathy has been described rarely in literature. (Med J Indones 2003; 12: 27-8)
\end{abstract}

Keywords: chronic lymphocytic leukemia; acute demyelinating polyneuropathy

Tumor infiltration of cranial and spinal nerve roots has been known as most common mechanism by which peripheral nervous system is affected in lymphoma and leukemia's but demyelinating polyneuropathy as complication or presentation is unusual and has been described less often in literature. ${ }^{1,2}$ Furthermore, neuropathy usually appears in patients with known malignancy, but rarely has it been the initial presentation of underlying malignancy. ${ }^{3} \mathrm{We}$ report a patient in whom acute demyelinating polyneuropathy preceded the diagnoses of chronic lymphocytic leukemia (stage 0) and which responded to prednisolone therapy. Response to steroid therapy suggests an autoimmune process as a cause of polyneuropathy.

\section{Case report}

A 56 years old gentleman was admitted with history of gradually progressive weakness in both upper and lower limbs. The weakness was more marked in distal muscle groups. There was no history of paresthesias

Department of Medicine, Postgraduate Institute of Medical Sciences, Rohtak, Haryana, India or sensory loss. There was no history of loss of consciousness, diplopia, drop attacks, dysarthria, dysphagia, and alcohol or drug intake. On clinical examination he was conscious and oriented. His pulse rate was 84/min regular and blood pressure was 130/86 mmHg. No pallor, cyanosis, clubbing, icterus, papilloedema, lymphadenopathy were detected. On neurological examination, higher mental functions, cranial nerves, sensory and cerebellar systems were normal. There were no signs of meningeal involvement. On motor system examination patient had a power of grade $4 / 5$ in both upper and lower limbs. He was able to walk with support; however, fine movements with fingers like buttoning his shirts were impaired. Deep tendon reflexes were preserved except loss of finger and ankle jerks on both sides. Plantars were silent bilaterally. There was no wasting of any muscle group. Cardiovascular, respiratory, abdominal system examinations did not reveal any abnormality. Keeping in view the clinical picture of patient, a provisional diagnosis of distal symmetric motor neuropathy involving both upper and lower limbs was made and appropriate investigations were sent. Investigations revealed $\mathrm{Hb} 13.6 \mathrm{gm} / \mathrm{dl}$ and W.B.C-36000/cumm. Differential leucocyte count showed $82 \%$ lymphocytes and peripheral blood picture showed many "smudge" cells with a picture suggestive of chronic lymphocyte 
leukemia. Platelet count was 1,60000/cumm. ESR was $13 \mathrm{~mm}$ in $1^{\text {st }}$ hour. Blood urea, serum creatinine, serum sodium, potassium, glucose were normal. X-ray chest PA view and ECG were normal. CSF examination revealed no abnormality. EMG and nerve conduction studies were done in both upper and lower limbs. Findings were suggestive of demyelinating motor-sensory polyneuropathy predominantly involving both lower limbs. Final diagnosis of chronic lymphocytic leukemia with demyelinating polyneuropathy was made. Patient was given prednisolone $60 \mathrm{mg}$ daily. No treatment for CLL was started since patient was in stage 0 as per Rai Staging of CLL. After the introduction of steroids, patient started showing improvement and was discharged after 10 days on tapering doses of steroid. On follow up examination patient was able to walk without support.

\section{DISCUSSION}

Acute polyneuropathy was reported more commonly associated with lymphomas particularly Hodgkin's disease than with leukemia's. There are very few case reports of acute demyelinating polyneuropathy in association with CLL. ${ }^{1,2}$ William et $\mathrm{al}^{4}$ reported some form of peripheral neuropathy in 2.25 percent of their 5,778 patients with lymphomas or leukemia's. The combination of CLL and peripheral neuropathy was seen only in three patients and none of these did it take the form of acute polyneuropathy. We recently encountered a patient who presented with acute motor sensory polyneuropathy and on investigation also found to be having stage 0 CLL. The acute onset of polyneuropathy actually had brought into picture the evidence of CLL. How, exactly CLL causes or is responsible for acute polyneuropathy is not clear. Both direct and indirect effects of leukemia cells on peripheral nervous system may be responsible. ${ }^{1}$ In some patients, the nerve or nerve roots are compressed or infiltrated by neoplastic cells. In others, metabolic, toxic or immunological factors may be responsible. However, response to steroid therapy would suggest that there is an autoimmune process directed at damaging the peripheral nervous tissue. Powles and Malpas ${ }^{5}$ had reported two cases of acute demyelinating polyneuropathy in association with CLL. Both these cases improved following steroid therapy. This patient also showed a remarkable recovery following steroid therapy, which points towards immunological nature of injury to peripheral nerves. Further, CLL presenting for first time as acute demyelinating neuropathy had not been reported previously. Most of the case reports are in patients already diagnosed of CLL. Thus the diagnosis of malignancy especially hematological malignancies should be suspected in middle aged or elderly patients with acute motor sensory, symmetrical polyneuropathy of obscure cause, in whom timely institution of steroid therapy may prove rewarding in changing the course of polyneuropathy.

\section{REFERENCES}

1. McLeod JG, Walsh JC. Peripheral neuropathy associated with lymphomas and other reticuloses. In: Dyck, PJ, Thomas PK, Lambert EH (eds): Peripheral neuropathy. Philadelphia, WB Saunders Company Inc; 1975, vol 2, p. 1314-25.

2. Croft PB, Urich H, Wilkinson M. Peripheral neuropathy of sensorimotor type associated with malignant disease. Brain 1977; 90:31-66.

3. Harris W. A case of leukemic polyneuritis. Lancet 1921; $1: 122$.

4. Williams HM, Diamond HD, Craver LF, et al. Neurological complications of lymphoma and leukemia's. Springfield, III, Charles C Thomas Publisher, 1959, p.86-100.

5. Powles RL, Malpas JS. Guillain-Barre syndrome associated with chronic lymphatic leukemia's. Br Med J $1967 ; 3: 286-7$. 